\title{
Resultater etter skadekirurgi i lavinntektsland
}

\author{
Det er relativt få infeksjoner etter margnagling av lårbeinsbrudd i lavinn- \\ tekts- og mellominntektsland, også i land der det er høy hivprevalens.
}

I mange land behandles pasienter med lårbeinsbrudd fortsatt med strekk og sengeleie i flere måneder. Dette er en behandlingsform vi forlot $\mathrm{i}$ vår del av verden for over 50 år siden. På verdensbasis dør det hvert år flere mennesker av skader enn av hiv/aids, tuberkulose og malaria til sammen. En myte som motarbeider innføring av moderne kirurgisk skadebehandling i lavinntektsland er at risikoen for postoperative infeksjoner er høy i disse landene.

I arbeidene som avhandlingen min bygger på, fant vi at infeksjonsratene slett ikke var så mye høyere enn i rike land, på tross av et mer alvorlig skadepanorama, få ressurser og dårlig infrastruktur. I en studie med pasienter som ble operert for lårbeins- brudd i Malawi fant vi at de ofte ikke kom til kontroll hvis de ikke hadde plager, fordi transporten tilbake til sykehuset var for dyr. I denne studien var over $70 \%$ av alle som brakk lårbeinet skadet i trafikken. Over $17 \%$ av pasientene var hivpositive. Det så ikke ut til at hivpositive skadepasienter hadde noen vesentlig økt risiko for infeksjon etter kirurgi, men de hadde muligvis noe økt dødelighet postoperativt.

Resultatene tyder på at fare for infeksjon eller høy hivprevalens ikke bør brukes som argument mot å innføre moderne skadebehandling i lavinntektsland.

\section{Sven Young}

svenyoung@gmail.com

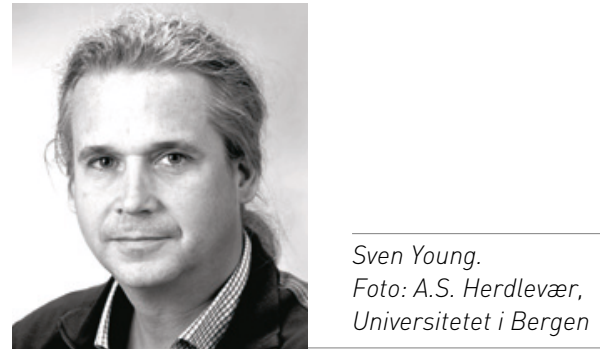

Disputas

Sven Young disputerte for ph.d.-graden ved Universitetet i Bergen 31.1. 2014. Tittelen på avhandlingen er Orthopaedic trauma surgery in low-income countries. Follow-up, infections and HIV.

\section{Genvarianter og psykotiske lidelsers alvorlighetsgrad}

\section{Genvarianter som kan gi økt risiko for psykotiske lidelser er assosiert med symptomalvorlighetsgrad, hjernestruktur og hjernefunksjon.}

Det er stor variasjon i symptomer, forløp og alvorlighetsgrad ved psykotiske lidelser. Kunnskapen om etiologi og underliggende biologiske prosesser er begrenset, men den estimerte heritabiliteten er høy. På tross av høy heritabilitet har det vært vanskelig å identifisere spesifikke genvarianter som er assosiert med sykdomsrisiko. Dette kan skyldes stor variasjon i både klinisk uttrykk og underliggende genetisk utrustning. Det er foreslått at genvarianter som er viktige for ulike biologiske mekanismer kan bidra til forskjellige aspekter, eller endofenotyper, ved lidelsene.

I min doktoravhandling undersøkte jeg enkeltnukleotidpolymorfismer (SNP-er) i gener som er viktige for glutmamat- og dopaminnevrotransmisjon (DTNBP1,DAO, COMT) og nevroutvikling (TCF4) samt eks- presjon av TCF4. Vi identifiserte genvarianter samt endret ekspresjonsmønster assosiert med alvorlighetsgrad av schizofrenisymptomer og assosiert med endringer i hjernens anatomi og funksjon hos både syke og friske.

Ved å avdekke det genetiske bidraget til endofenotyper ved psykotiske lidelser kan vi få en bedre forståelse av den komplekse patofysiologien til disse sykdommene og forstå graden av overlapping mellom ulike alvorlige psykiatriske sykdommer. Doktorgradsarbeidet har bidratt til økt kunnskap om genetiske risikofaktorer ved schizofreni og bipolar lidelse og økt forståelse for hvordan disse kan spille en rolle i patofysiologien ved lidelsene.

\section{Katrine Verena Wirgenes}

k.v.wirgenes@medisin.uio.no

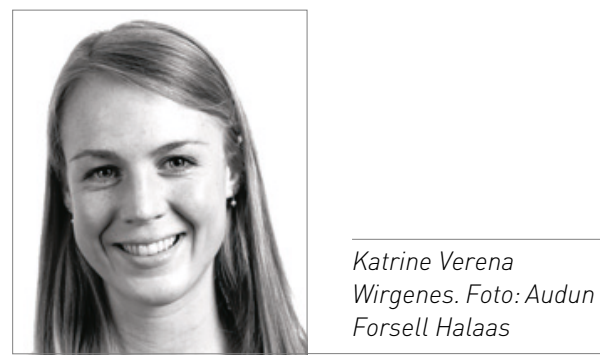

Disputas

Katrine Verena Wirgenes disputerte for ph.d.graden ved Universitetet i Oslo 4.12. 2013. Tittelen på avhandlingen er Genetic factors in schizophrenia associated with endophenotypes. 